\title{
Sosialisasi Pentingnya Penerapan 3M di Era New Normal Desa Riding Panjang
}

\author{
Dita Hardiani' , Hazbi an Yasypiaka² ${ }^{2}$ Muhammad Nur Hidayat ${ }^{3}$, Siti Nursiah ${ }^{4}$, Bayu Pratama ${ }^{5}$ \\ 1Program Studi PGSD, Fakultas FKIP, Universitas Muhammadiyah Bangka Belitung \\ 2Program Studi PJKR, Fakultas FKIP, Universitas Muhammadiyah Bangka Belitung \\ 3Program Studi PJKR, Fakultas FKIP, Universitas Muhammadiyah Bangka Belitung \\ ${ }^{4}$ Program Studi PBI, Fakultas FKIP, Universitas Muhammadiyah Bangka Belitung \\ ${ }^{5}$ Program Studi PJKR, Fakultas FKIP, Universitas Muhammadiyah Bangka Belitung \\ e-mail: ditahardiani26@gmail.com, hazbianyasypiaka@gmail.com, ahmadbelinyu@gmail.com \\ sitinursiah25@gmail.com, bayu27785@gmail.com
}

\begin{abstract}
Abstrak
Pandemi Covid-19 telah memberikan dampak bagi semua lapisan masyarakat tidak terkecuali masyarakat Bangka. Kasus positif Covid-19 di Desa Riding Panjang juga masih relatif tinggi dan terus bertambah. Hal ini berakibat tingkat penularannya pun menjadi tinggi. Oleh karena itu, masalah ini perlu diperhatikan agar secepatnya dilakukan penanganan untuk dapat membantu menaggulangi penularan Covid-19. Kesadaran masyarakat akan pentingnya mentaati protokol kesehatan masih sangat minim, hal inilah yang kemudian menjadi penyebab utama penularan virus Covid-19. Berdasarkan permasalahan tersebut, perlu adanya kesadaran masyarakat untuk mengubah pola perilaku agar lebih mematuhi protokol kesehatan dalam menanggulangi penyebaran Covid-19. Dengan itu, pentingnya melakukan suatu upaya yang dapat menyadarkan pola pikir masyarakat betapa pentingnya mematuhi protokol kesehatan, yaitu dengan menyelenggarakan kegiatan sosialisasi dalam rangka mencegah penyebaran Covid-19. Sosialisasi ini dilakukan di Dusun Bukit Tulang Desa Riding Panjang Kecamatan Belinyu Kabupaten Bangka Provinsi Kepulauan Bangka Belitung. Adapun kegiatan yang dicapai dari sosialisasi ini yaitu masyarakat lebih peduli dalam mematuhi protokol kesehatan seperti memakai masker, menjaga jarak, dan mencuci tangan.
\end{abstract}

Kata kunci: sosialisasi, penerapan 3M, Covid-19

\begin{abstract}
The Covid-19 pandemic has had an impact on all levels of society, including the people of Bangka. Positive cases of Covid-19 in Riding Panjang Village are still relatively high and continue to grow. This results in a high transmission rate. Therefore, this problem needs to be considered so that it is handled as soon as possible to help prevent the spread of Covid-19. Public awareness of the importance of adhering to health protocols is still very minimal, this is what has become the main cause of transmission of the Covid-19 virus. Based on these problems, there is a need for public awareness to change behavior patterns to better comply with health protocols in tackling the spread of Covid-19. With that, it is important to make an effort that can make the public's mindset aware of the importance of complying with health protocols, namely by holding outreach activities in order to prevent the spread of Covid-19. This socialization was conducted in Bukit Tulang Hamlet, Riding Panjang Village, Belinyu District, Bangka Regency, Bangka Belitung Islands Province. As for the activities achieved from this socialization, the community is more concerned with complying with health protocols such as wearing masks, maintaining distance, and washing hands.
\end{abstract}

Keywords: socialization, 3M implementation, Covid-19

\section{PENDAHULUAN}

Latar belakang penelitian ini adalah sosialisasi pentingnya penerapan 3M di era new normal dan juga merupakan suatu program Kemenkes yang mulai diberlakukan sejak 8 Desember 2020 lalu sebagai bentuk tindakan dalam melawan Covid-19 sekaligus untuk mencegah penyebaran pandemi Covid-19. Penerapan 3M itu sendiri terdiri dari penerapan memakai masker, menjaga jarak, dan mencuci tangan.

Semua media baik cetak maupun elektronik dan bahkan media online menayangkan peraturan untuk menerapkan $3 \mathrm{M}$ sebagai informasi kepada masyarakat Indonesia agar 
mematuhi peraturan yang telah dianjurkan sehingga penyebaran Covid-19 di Indonesia menurun.

Indonesia telah mencapai 1,2 juta kasus positif Covid-19 terhitung sampai tanggal 20 Februari 2021. Sementara itu, Provinsi Kepulauan Bangka Belitung khususnya di wilayah Kabupaten Bangka kasus aktif Covid-19 telah mencapai 1.775 kasus yang telah terkonfirmasi dan Kecamatan Belinyu telah terkonfirmasi mencapai 126 kasus terkonfirmasi.

Salah satu pihak dari lembaga Pencegahan dan Pengendalian Penyakit menilai bahwa banyaknya kasus terkonfirmasi saat ini adalah gambaran dari belum optimalnya penerapan 3M diseluruh tatanan kehidupan. Masih banyak masyarakat yang enggan memakai masker ada juga yang memakai masker namun belum tepat seperti meletakkannya didagu serta tidak menutupi hidung dan mulut secara keseluruhan.

Peningkatan kasus COVID-19 yang terjadi di masyarakat didukung oleh proses penyebaran virus yang cepat, baik dari hewan ke manusia ataupun antara manusia. Proses penularan COVID-19 kepada manusia harus diperantarai oleh reservoir kunci yaitu alphacoronavirus dan betacoronavirus yang memiliki kemampuan menginfeksi manusia. Kontak yang erat dengan pasien terinfeksi COVID-19 akan mempermudah proses penularan COVID-19 antara manusia. Proses penularan COVID-19 disebabkan oleh pengeluaran droplet yang mengandung virus SARS-CoV-2 ke udara oleh pasien terinfeksi pada saat batuk ataupun bersin. Droplet di udara selanjutnya dapat terhirup oleh manusia lain di dekatnya yang tidak terinfeksi COVID-19 melalui hidung ataupun mulut. Droplet selanjutnya masuk menembus paru-paru dan proses infeksi pada manusia yang sehat berlanjut [1]

Untuk mencegah penyebaran Virus COVID19 maka pemerintah Indonesia mempunyai beberapa kebijakan untuk memutus mata rantai penyebaran virus, diantaranya menghimbau agar masyarakat Indonesia melakukan penerapan 3M (memakai masker, mencuci tangan atau menggunakan hand sanitizer, menjaga jarak) [2]. Langkah-langkah utama yang hendak dilaksanakan masyarakat agar dapat mengurangi dan mengantisipasi penyebaran Covid-19 yaitu seperti penggunaan masker; menutup mulut dan hidung saat bersin ataupun batuk; mencuci tangan secara teratur dengan sabun atau desinfeksi dengan pembersih tangan yang mengandung setidaknya $60 \%$ alkohol; menghindari kontak dengan orang yang terinfeksi; menjaga jarak dari orang-orang; dan menahan diri dari menyentuh mata, hidung, dan mulut dengan tangan yang tidak dicuci [3]

Menurut Yanti, Ni Putu Emy Darma (2020: 492) [4]pengetahuan dan tindakan yang nyata dari pemerintah dan masyarakat terkait PHBS akan mampu menurunkan jumlah kasus COVID-19, sehingga masa pandemi COVID-19 dapat berakhir dengan cepat. Kartono dalam penelitian yang berjudul Pembatasan Sosial Berskala Besar (PSBB) dan Pidana Denda Dalam Rangka Pencegahan dan Pemberantasan Virus Covid-19 menyimpulkan bahwa peran pemerintah harus tegas dalam menerapkan sanksi pidana dan pidana denda sebagai alternatif untuk membuat masyarakat jera, teredukasi dan sebagai sarana pengendalian sosial [5] Oleh karena itu, penelitian ini bertujuan untuk memberikan informasi terkait pentingnya sosialisasi penerapan 3M khususnya pada masyarakat Dusun Bukit Tulang Desa Riding Panjang.

\section{METODE}

Metode yang dilakukan yaitu melalui sosialisasi untuk mengantisipasi masyarakat Dusun Bukit Tulang Desa Riding Panjang terkait upaya pencegahan penyebaran COVID-19 dengan beberapa cara berikut: 
1. Metode observasi lapangan, dilakukan untuk memetakan tempat dan lokasi pembagian masker dan hand sanitizer kepada masyarakat khususnya di Dusun Bukit Tulang Desa Riding Panjang;

2. Sosialisasi kegiatan, dilakukan dengan mendatangi masyarakat secara langsung dari rumah ke rumah Dusun Bukit Tulang dan memberikan informasi terkait pentingnya penerapan 3M; serta membagikan masker dan hand sanitizer kepada masyarakat;

Berikut beberapa tahapan sosialisasi yang dilakukan oleh tim pengabdian sebagai berikut:

\section{a. Tahap 1 Observasi Lapangan}

Tim pengabdian melakukan kegiatan observasi lapangan yaitu di Dusun Bukit Tulang Desa Riding Panjang untuk memetakan tempat dan lokasi pembagian masker dan hand sanitizer kepada masyarakat.

\section{b. Tahap 2 Kegiatan Perizinan}

Tim Pengabdian meminta izin kepada Kepala Dusun Bukit Tulang terkait kegiatan sosialiasi yang akan dilaksanakan. Sosialisasi ini bertujuan untuk memberikan gambaran tentang disiplin protokol kesehatan Covid-19 sekaligus pembagian masker dan hand sanitizer kepada masyarakat.

\section{c. Tahap 3 Kegiatan Sosialisasi}

Sosialisasi disiplin protokol kesehatan Covid-19 dilakukan pada Senin, tanggal 15 Februari 2021. Sosialisasi dilakukan dengan tetap memperhatikan protokol kesehatan, menggunakan masker, menerapkan kebiasaan cuci tangan dan penggunaan hand sanitizer, serta pembatasan jarak sosial. Sosialisasi yang dilaksanakan oleh tim pengabdian di lakukan dengan mendatangi dari rumah ke rumah dengan beberapa kelompok tim pengabdian. Jadi setiap rumah didatangi oleh 2 orang dari tim pengabdian agar kegiatan sosialisasi dapat berjalan secara efektif dan efisien.

\section{d. Tahap 4 Publikasi Sosialisasi Penerapan 3M Melalui Digital Platform}

Untuk memperluas kegiatan sosialisasi pentingnya penerapan $3 \mathrm{M}$, tim pengabdian melakukan publikasi terkait hal tersebut melalui digital platform berupa foto melalui sosial media Instagram. Harapannya, melalui akses online masyarakat yang telah melek digital bisa memperoleh informasi secara online dan mudah diakses menggunakan koneksi internet dan gadget yang mendukung. Kegiatan sosialisasi secara online ini tidak hanya ditujukan kepada masyarakat Dusun Bukit Tulang, namun kegiatan ini juga ditujukan kepada masyarakat luas yang dapat dengan mudah mengakses informasi secara online [6]

\section{HASIL DAN PEMBAHASAN}

Kegiatan sosialisasi ini dilakukan pada bulan Februari 2021. Sesuai dengan metode pelaksanaan yang telah dipaparkan sebelumnya, kegiatan sosialisasi ini dilakukan melalui empat tahapan dengan beberapa program utama yaitu (1) sosialisasi pentingnya penerapan 3M, (2) pembagian masker dan hand sanitizer, (3) penyebaran poster, dan (4) publikasi sosialisasi penerapan 3M melalui digital platform.

Sosialiasi dilakukan dengan tetap mematuhi protokol kesehatan 3M sehingga tim pengadian dibagi menjadi 5 kelompok dengan setiap kelompok terdiri dari 2 mahasiswa pengabdian. Metode penyuluhan dilakukan melalui ceramah. Kemudian dilakukan pemberian masker, hand sanitizer, serta poster kepada setiap rumah yang ada di Dusun Bukit Tulang Desa 
Riding Panjang Kecamatan Belinyu. Sosialisasi berhasil dilakukan secara kondusif tanpa ada pengumpulan massa sehingga kegiatan sosialisasi dapat berjalan lebih efektif dan efisien.

WHO (World Health Organization) mengatakan bahwa sosialisasi dan juga pemberian edukasi tentang pencegahan serta penularan Covid-19 merupakan salah satu upaya yang bisa kita lakukan, dalam upaya untuk mengurangi penyebaran virus corona atau covid 19 ini. Covid19 dapat menular dari orang yang terinfeksi kepada orang lain di sekitarnya melalui percikan, batuk atau bersin. Covid-19 juga dapat menular melalui benda-benda yang terkontaminasi percikan batuk atau bersin penderita Covid-19. Orang lain yang menyentuh benda-benda terkontaminasi tersebut lalu menyentuh mata, hidung dan mulut mereka dapat tertular penyakit covid-19 ini baik secara langsung maupun tidak langsung)[7]

Di Indonesia sendiri menurut catatan Satuan Petugas Covid-19, dilaporkan penambahan kasus infeksi per hari pada 23 Februari 2021 mencapai 9.775 kasus. Jumlah ini merupakan hasil tracing melalui pemeriksaan sebanyak 65.431 spesimen yang dilakukan dengan metode real time polymerase shain reaction (PCR) dan tes cepat molekuler (TCM).

Selain itu, juga dilaporkan kasus yang sembuh dari Covid-19 pada 23 Februari 2021 tercatat bertambah 9.918, sehingga totalnya menjadi 1.104 .990 orang. Sementara itu jumlah yang meninggal juga kembali bertambah 323, sehingga totalnya menjadi 35.014 orang. Jumlah suspek Covid-19 kini sebanyak 78.616 orang. Dan kasus aktif sebanyak 158.604 orang. Saat ini kasus Covid-19 tersebar di 510 Kabupaten/Kota di 34 Provinsi.

Presiden RI Joko Widodo pada Kamis (24/09/2020), menerima Menteri Pemberdayaan Perempuan dan Perlindungan Anak (PPPA) I Gusti Ayu Bintang Puspayoga memberikan arahan untuk melakukan kampanye dan sosialisasi masif kepada para keluarga untuk mencegah penyebaran Covid-19.

Pada kesempatan itu juga Joko Widodo memberikan arahan kepada menteri PPPA serta jajarannya tentang bagaimana kita mengampanyekan dan sosialisasi masif kepada para keluarga utamanya perempuan dan anak yang ada di seluruh Tanah Air. Menteri PPPA mengatakan, bentuk kampanye dan sosialisasi yang dilakukan ialah dengan menggaungkan imbauan mengenai pemakaian masker, mencuci tangan secara berkala, dan menjaga jarak aman antarsesama (3M). Sosialisasi tersebut nantinya akan turut melibatkan lembaga atau pemerhati perempuan, termasuk Pemberdayaan Kesejahteraan Keluarga (PKK). Beliau juga menambahkan bahwa penerapan 3M atau disiplin terhadap protokol kesehatan saat ini menjadi kunci untuk mencegah penyebaran Covid-19, termasuk di lingkungan keluarga. Hal tersebut harus menjadi perhatian dan disadari para anggota keluarga meski berada di dalam rumah.

Sejalan dengan hal di atas menurut pendapat Fakhlur (2021: 141)[8] beberapa kebijakan yang telah dilakukan oleh Pemerintah sebagai upaya memutuskan rantai penyebaran Covid-19 tersebut tentunya perlu diapresiasi karena hal tersebut bagian dari kepedulian pemerintah terhadap rakyatnya. Selain itu, masyarakat juga memiliki peran penting dalam memutus mata rantai penularan COVID-19 agar tidak menimbulkan sumber penularan baru/cluster pada tempat-tempat dimana terjadinya pergerakan orang, interaksi antar manusia dan berkumpulnya banyak orang. Masyarakat harus dapat beraktivitas kembali dalam situasi pandemi COVID-19 dengan beradaptasi pada kebiasaan baru yang lebih sehat, lebih bersih, dan lebih taat, yang dilaksanakan oleh seluruh komponen yang ada di masyarakat serta memberdayakan semua sumber daya yang ada. Peran masyarakat untuk dapat memutus mata rantai penularan COVID19(risiko tertular dan menularkan) harus dilakukan dengan menerapkan protokol kesehatan melalui perlindungan kesehatan individu dan perlindungan kesehatan masyarakat)[9].

Dengan demikian kegiatan kampanye, sosialisasi, maupun penyuluhan terkait program 3M sangat penting untuk dilakukan khususnya kepada masyarakat di desa sehingga informasi 
dan edukasi terkait Covid-19 dapat diketahui secara merata. Selain itu, BNPB mengatakan bahwa perubahan perilaku untuk menangani permasalahan penularan COVID-19, yaitu dengan mendorong percepatan perubahan perilaku masyarakat agar secara konsisten menjalankan 3M. Perubahan perilaku manusia terjadi akibat dua dorongan, yakni dorongan dari dalam diri sendiri dan dorongan dari luar. Idealnya,perubahan perilaku berasal dari kesadaran dalam diri. Untuk menciptakan motivasi internal ini, akan dilakukan edukasi dan sosialisasi secara [10]

\section{Gambar}

Berikut ini beberapa foto yang berhasil didokumentasikan pada saat kegiatan:

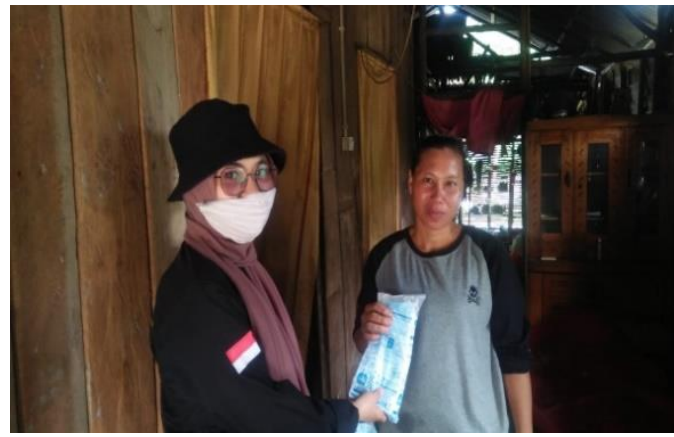

Gambar 1. Kegiatan Pembagian Masker

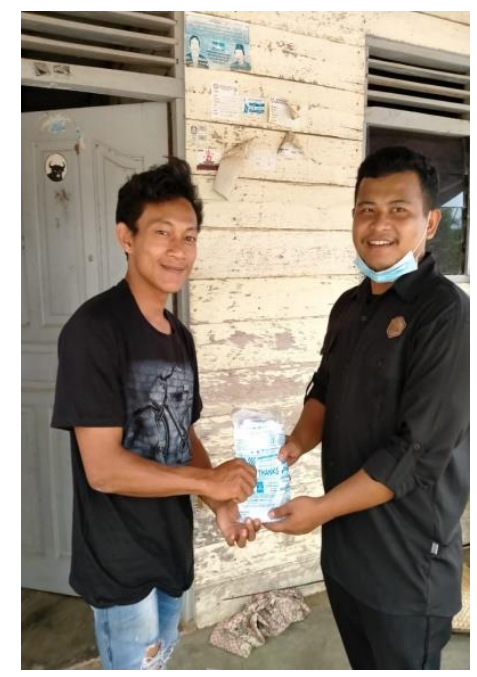

Gambar 2. Kegiatan Sosialisasi serta Pembagian Hand Sanitizer

\section{KESIMPULAN}

Upaya yang dapat dilakukan untuk memutus rantai penularan virus Covid-19 salah satunya dengan terus menggalakkan penerapan 3M kepada masyarakat. Kegiatan pembagian masker secara gratis, himbauan kepada seluruh masyarakat untuk menjaga jarak dan sering mencuci tangan merupakan hal-hal yang harus selalu diingat dan diterapkan oleh seluruh masyarakat Indonesia pada khususnya. Informasi dan edukasi harus terus menerus disampaikan kepada masyarakat, serta pengawasan juga harus dilakukan agar masyarakat mau menerapkan perilaku sehat demi mengantisipasi penyebaran Covid-19. Kegiatan sosialisasi dan penyuluhan merupakan salah satu cara yang sangat efektif dilakukan untuk mengedukasi masyarakat. 


\section{DAFTAR PUSTAKA}

[1] M. A. Shereen, S. Khan, A. Kazmi, N. Bashir, and R. Siddique, "COVID-19 infection: Origin, transmission, and characteristics of human coronaviruses," J. Adv. Res., vol. 24, pp. 91-98, 2020.

[2] F. Apriliany, R. O. Umboro, V. F. Ersalena, P. Farmasi, F. Kesehatan, and U. Bumigora, "Jurnal abdidas," vol. 2, no. 1, pp. 41-47, 2021.

[3] F. Di Gennaro et al., "Coronavirus diseases (COVID-19) current status and future perspectives: A narrative review," Int. J. Environ. Res. Public Health, vol. 17, no. 8, 2020.

[4] N. P. E. D. Yanti, I. M. A. D. P. Nugraha, G. A. Wisnawa, N. P. D. Agustina, and N. P. A. Diantari, "Public Knowledge about Covid-19 and Public Behavior During the Covid-19 Pandemic," J. Keperawatan Jiwa, vol. 8, no. 4, p. 491, 2020.

[5] I. Santosa, P. Ponoharjo, and ..., "Mewujudkan Masyarakat Siaga Covid-19 di Kelurahan Mintaragen Kecamatan Tegal Timur Kota Tegal Melalui Kegiatan KKN Tematik," Community Empower., vol. 6, no. 1, pp. 1-11, 2021.

[6] L. Farokhah, Y. Ubaidillah, and R. A. Yulianti, "Penyuluhan Disiplin Protokol Kesehatan Covid-19 Di Kelurahan Gandul Kecamatan Cinere Kota Depok," Semin. Nas. Pengabdi. Masy. LPPM UMJ, pp. 1-8, 2020.

[7] K. I. Pengajian, D. I. Perumahan, and V. Bukit, "SOSIALISASI DAN EDUKASI TENTANG PENCEGAHAN COVID-19 PADA," vol. 2, no. 1, pp. 415-419, 2021.

[8] Fakhlur, "Meningkatkan Kesadaran Hukum Masyarakat Untuk Menjalankan 3 M ( Memakai Masker , Mencuci Tangan Dan Menjaga Jarak)," Hermeneutika, vol. 5, no. 1, pp. 138-140, 2021.

[9] D. Puspitaningsih, S. Rachmah, S. Tinggi, I. Kesehatan, M. Mojokerto, and P. Kesehatan, "Peningkatan Pengetahuan Dan Kesadaran Masyarakat Dalam Penerapan Protokol Kesehatan 3M Di Wilayah Pasar Kemlagi," J. Abdimakes, vol. 1, no. 1, pp. 39-46, 2020.

[10] I. Lisni, E. Sutrisno, D. Mardiyah, S. Suherdin, and ..., "Penyuluhan Protokol Kesehatan Pencegahan Dan Pengendalian Covid-19 Di Panti Asuhan Baitul Arief Kota Bandung," J. ASTA Abdi Masy. Kita, vol. 01, no. 01, pp. 32-46, 2021. 